January 2022

\title{
Experience Peer-Review With SRJ
}

Tierra Holmes

tierra.holmes@sjsu.edu

Follow this and additional works at: https://scholarworks.sjsu.edu/ischoolsrj

Part of the Archival Science Commons, Cataloging and Metadata Commons, Collection Development and Management Commons, Information Literacy Commons, Museum Studies Commons, Scholarly Communication Commons, and the Scholarly Publishing Commons

\section{Recommended Citation}

Holmes, T. (2022). Experience Peer-Review With SRJ. School of Information Student Research Journal, 11(2). https://doi.org/10.31979/2575-2499.110201 Retrieved from https://scholarworks.sjsu.edu/ ischoolsrj/vol11/iss $2 / 1$

This article is brought to you by the open access Journals at SJSU ScholarWorks. It has been accepted for inclusion in School of Information Student Research Journal by an authorized administrator of SJSU ScholarWorks. For more information, please contact scholarworks@sjsu.edu. 


\section{Experience Peer-Review With SRJ}

\section{About Author}

Tierra Holmes graduated from the University of North Carolina at Charlotte with a B.A. in History and a B.A. in Art History. She served as the editor-in-chief (EIC) of Sanskrit Literary-Arts Magazine during her senior year as an undergraduate and is excited to serve as the EIC of $S R J$ as well. She anticipates graduating from SJSU's MLIS program this Spring. 
In our welcome video to Master of Library and Information Science (MLIS) students completing San Jose State University's (SJSU) introductory course on information communities, we discussed the importance of peer-review as a standard for ensuring the integrity of academic research (SLIS Student Research Journal, 2021). With this in mind, the Student Research Journal (SRJ) has renewed its commitment to providing a valuable experience to both our readers and graduate students in Library and Information Science (LIS) and related fields who wish to experience peer-review and academic publishing. The editors and authors who have tirelessly worked to make this issue possible have demonstrated an astounding dedication to $S R J$ 'S vision, despite enduring the unprecedented circumstances wrought by living through a global pandemic.

Dr. Mary K. Bolin, a lecturer at SJSU and Professor Emeritus at University of Nebraska-Lincoln Libraries, has contributed a wonderfully thought-provoking piece on academic libraries as collaborative spaces. Her study explores the relationship between writing centers and libraries at public research universities as part of a logical evolution of library services.

SJSU MLIS candidate Mateo Campos-Seligman offers an insightful review of Campana and Mills' Create, Innovate, and Serve: A Radical Approach to Children's and Youth Programming. Campos-Seligman discusses how Campana and Mills build upon work by Dresang to develop a progessive new resource for children's and youth services librarians and identifies areas of further study.

Jessica Nombrano Larsen, another SJSU MLIS candidate, provides a discerning review of Leung and Lopez-McKnight's exceedingly relevant Knowledge Justice: Disrupting Library and Information Studies Through Critical Race Theory. Larsen discusses Leung and Lopez-McKnight's use of Critical Race Theory (CRT) to confront the lack of diversity in the LIS field and offers suggestions for further research and how the book could be used to educate future LIS students.

This issue, though succinct, is a testament to both the skill and passion cultivated by students at SJSU's School of Information. After 10 years of excellence, we hope that you, our supporters and readers, will continue to be part of the $S R J$ experience as we endeavor to become a valuable resource for graduate LIS writing at SJSU and abroad. We look forward to forging meaningful connections with students as they begin their journey into academic publishing, for decades to come.

\section{Acknowledgements}

I can scarcely find the words to express my profound appreciation for the diligence displayed by SRJ's editors during the Fall 2021 semester. Our Managing Editor, 
Meghan Duffey, assumed her role at a critical time for $S R J$ and has done a remarkable job. This issue would not have been possible without her thoughtful insight. In addition to providing astute feedback for prospective authors, our Editorial Team has demonstrated an exceptional level of commitment with their willingness to take on extra assignments and special projects that elevate SRJ'S vision.

Our Faculty Advisor, Dr. Anthony Bernier, has been an invaluable guiding force for the journal. He has helped SRJ's editors cultivate the skills we needed to publish this issue through our own merit.

We would also like to offer our sincere gratitude to the Faculty Advisory Board, led by iSchool Director Dr. Anthony Chow and Associate Director Dr. Linda Main, for their continued support. By enabling students across the globe to experience the peer-review process, $S R J$ also hopes to uphold the values of our institution and increase SJSU's research profile by establishing our journal as a premiere source for graduate research in LIS and related fields.

\section{References}

SLIS Student Research Journal. [SJSU's iSchool Student Research Journal]. (2021, December 28). INFO 200 Welcome Video [Video]. YouTube. https://www.youtube.com/watch?v=US3ityZNTP4 